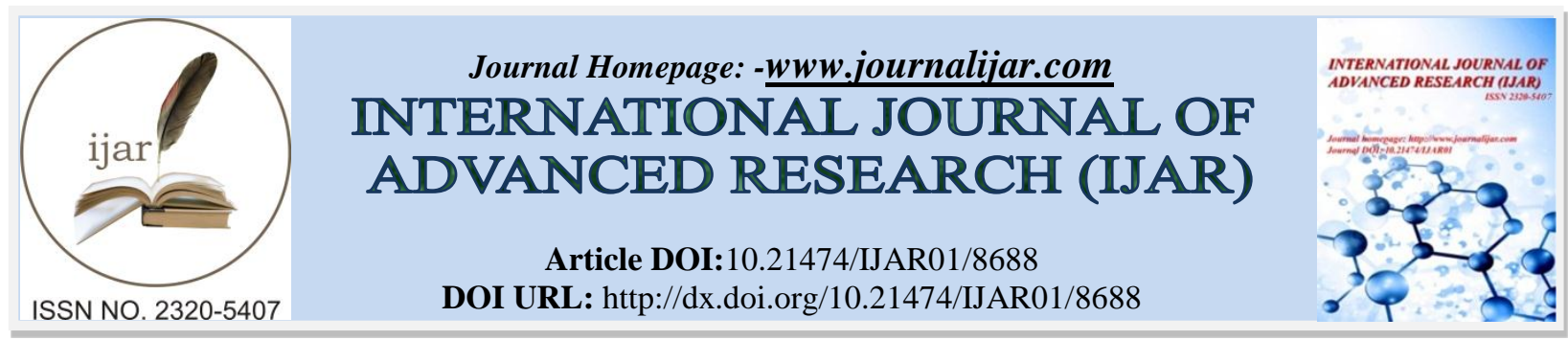

RESEARCH ARTICLE

\title{
USE OF MEDICINAL PLANTS DURING THE GESTATIONAL PERIOD.
}

Dayane de Melo Barross ${ }^{1}$, Marcela de Albuquerque Melo ${ }^{1}$, Andreza Roberta de França Leite ${ }^{2}$, Gesikelly Lopes da Silva ${ }^{2}$, Normanda Pereira da Silva ${ }^{3}$, Luana Mayara Bezerra de Souza ${ }^{3}$, Adriana Maria da Silva Miranda $^{4}$, Maria José de Lima Silva ${ }^{5}$, Lucimara Martins da Silva ${ }^{6}$, Hosmany Bezerra Ramos ${ }^{7}$, Geraldo José Santos Oliveira ${ }^{8}$, Flávia Juliana Alves dos Santos ${ }^{9}$, Tamiris Alves Rocha ${ }^{10}$ and Danielle Feijó de Moura ${ }^{1}$.

1. Mestre em Saúde Humana e Meio Ambiente - Centro Acadêmico de Vitória, Universidade Federal de Pernambuco, CAV/UFPE - Pernambuco, Brasil.

2. Bacharel em Nutrição - Centro Acadêmico de Vitória, Universidade Federal de Pernambuco, CAV/UFPE Pernambuco, Brasil.

3. Discente de bacharelado em Nutrição - Centro Acadêmico de Vitória, Universidade Federal de Pernambuco, CAV/UFPE - Pernambuco, Brasil.

4. Especialista em Saúde Mental, Álcool e outras Drogas - Faculdade Escritor Osman Da Costa Lins, FACOL Pernambuco, Brasil.

5. Especialista em Gestão de Políticas Públicas - Instituto Nacional de Ensino, Sociedade e Pesquisa, INESP Pernambuco, Brasil.

6. Especialista em Fisioterapia Neurofuncional - Faculdade Estácio - Pernambuco, Brasil.

7. Especialista em Fisiologia do Exercício - Faculdade Boa Viagem, FBV - Pernambuco, Brasil.

8. Bacharel em Educação Física - Centro Acadêmico de Vitória, Universidade Federal de Pernambuco, CAV/UFPE - Pernambuco, Brasil.

9. Graduada em Fonoaudiologia - Universidade Católica de Pernambuco, UNICAP - Pernambuco, Brasil.

10. Doutora em Ciências Biológicas - Universidade Federal de Pernambuco, UFPE - Pernambuco, Brasil.

\section{Manuscript Info}

Manuscript History

Received: 13 January 2019

Final Accepted: 15 February 2019

Published: March 2019

Key words:-

Tea, gestation, pregnancy, medicinal plants.

\section{Abstract}

Objective: To gather studies on the effects of the use of medicinal plants during the gestational period, as a way of evidencing the effects caused by consumption. Methodology: The articles were searched in the electronic databases PubMed and Sciello. The articles published in the period 2007 to 2017 were included, using the descriptors: "tea", "medicinal plants", "phytotherapy" and "gestation" or "pregnancy", in Portuguese and English. Results: In the search of articles, 819 results were obtained, of which 39 articles were selected, according to the defined inclusion criteria. Conclusion: Information on the safe use of herbal products during pregnancy is still poorly understood, and further studies of plant species that may pose some risk during pregnancy are needed.

Copy Right, IJAR, 2019,. All rights reserved.

\section{Introduction:-}

Gestation is a unique experience in a woman's life. During this phase, several physiological changes happen for the arrival of the baby and in response to these changes, pregnant women are susceptible to the appearance of some common discomforts of the period such as nausea, vomiting, constipation, heartburn, indigestion, some pain and

Corresponding Author:-Dayane de Melo Barros.

Address:-Mestre em Saúde Humana e Meio Ambiente - Centro Acadêmico de Vitória, 
worry (SANFELICE et al., 2013; BRASIL, 2014; GABBE, 2015; CAMARGO, 2015). For this reason, many women try to alleviate these symptoms with medicinal herbs, believing them safer, and most of the plants for consumption are usually indicated by friends or relatives (NORDENG and HAVNEN, 2004).

In view of this, it can be seen how the knowledge about the use of medicinal plants is passed from generation to generation, moreover, it is commonly transmitted through a female figure, be it grandmother, mother or older sister (BADKE et al., 2012). The image of "natural" as something "safe" arouses the interest of pregnant women in the use of medicinal plants, presuming that there are no harmful effects on the concept (NORDENG and HAVNEN, 2004; PIRES and ARAÚJO, 2011; CAMARGO, 2015; ANHESI et al., 2016; NUNES and MACIEL, 2016). However, the scientific knowledge about the safety and consequences of the use of these herbs during this period is still insufficient (ANHESI et al., 2016).

Although scarce, there are studies with plants widely used in the gestational period that have substances with embryotoxic or teratogenic potential (ANHESI et al., 2016). Frequent consumption of medicinal plants without medical guidance can lead to greater problems depending on the period of use (CAMPOS et al., 2016). The consumption of any medicinal plant should be waived during the first three months, since studies on fetal malformation and toxicity from the use of medicinal herbs are still under development (CAMARGO, 2015).

It is known that the population has the freedom to cultivate and use its own Natural Remedy (medicinal plants) at home, but for this it is necessary the minimum knowledge about the plant or about its benefits or damages under the health of individuals (CAMARGO, 2015). Thus, the present study proposed to gather scientific findings about the effects of the use of medicinal plants during the gestational period.

\section{Methodology:-}

This is a systematic review of the literature. The search for scientific articles was carried out in the electronic databases PubMed and Sciello, using as descriptors: "tea", "medicinal plants", "phytotherapy" and "gestation", in Portuguese and English, with a 10-year time cut between 2007 and 2017. The articles were then translated and analyzed for information collection.

\section{Results:-}

A total of 819 results were obtained, of which 39 articles were included in the PubMed and Scielo database. In the course of the selection, articles that were not related to the topic or were outside the established time frame were disregarded. After the filtration of the articles according to the defined inclusion criteria were condensed the effects of plants and their extracts commonly used by pregnant women as described below:

\section{Chamomile}

Chamomilla (Chamomilla recutita) is a medicinal plant widely known for its properties: soothing, antipyretic and antispasmodic (BRASILEIRO et al., 2008). However, it is contraindicated for pregnant women because it is also emenagogue (stimulates blood flow in the pelvic region and uterus) and relaxes smooth muscle. An in vivo study aimed to evaluate the effects of the aqueous extract of camomile on gestation and on the pups generated in female rats of the Wistar line and showed that the chamomile can influence both the maternal weight gain during pregnancy and the pups after birth, besides being able to cause alterations in the neurological reflexes (ARRUDA et al., 2013).

In another study, premature constriction of the fetal ductus arteriosus associated with maternal consumption of chamomile tea was observed. Ductal constriction related to the consumption of chamomile tea possibly acts through a pharmacological mechanism similar to that of Nonsteroidal anti-inflammatory drugs (NSAIDs). Repeated and prolonged exposure to this tea may compensate for its relatively low anti-inflammatory effects (SRIDHARAN, ARCHER and MANNING, 2009). In addition, human testing has shown that urinary levels of chamomile tea metabolites may be present in the urine within 14 days after exposure to the substance, explaining its long-term metabolic effect (SRIDHARAN, ARCHER and MANNING, 2009).

The identification of this plant as an etiological factor of premature constriction of the fetal ductus arteriosus is of significant importance, since its suspension may result in reversal of changes in ductal dynamics (SRIDHARAN, ARCHER and MANNING, 2009). 


\section{Black tea}

A study carried out with puerperae aimed to determine if the levels of oxidants and antioxidants present in breast milk were affected by the consumption of black tea (Camellia sinensis) during pregnancy. Breast milk was obtained from 30 mothers and analyzed for lipid peroxidation based on malondialdehyde (MDA) and reduced glutathione levels (GSH). The highest level of MDA detected was $11.25 \mathrm{nmol} / \mathrm{mL}$, where the participant consumed 2 cups of tea per day. The lowest level of MDA was $3.03 \mathrm{nmol} / \mathrm{mL}$, which was associated with consumption of 1 cup of tea per day. The highest level of GSH detected was $344.94 \mathrm{nmol} / \mathrm{mL}$, referring to a mother who reported consumption of 1 cup of tea per day, while the lowest detected level was $29.28 \mathrm{nmol} / \mathrm{mL}$, associated to the consumption of 8 cups of tea per day. Thus, mothers who consume large amounts of black tea do not have higher levels of antioxidants and lower levels of oxidative damage in their breast milk. Another test performed with pregnant women showed that consumption of black tea may reduce the bioavailability of folic acid. (KAYIRAN et al., 2013), however, another study indicates that the reduction in folic acid concentration is more associated with green tea consumption because it has a higher epicatechin content than black tea (ALEMDAROGLU et al., 2008).

\section{Boldo}

The boldo (Peumus boldus) is an herbaceous plant that has active principles of terpene nature (guaieno, fenchona, barbatusina and colenol) with potential abortive properties (RUIZ et al., 2008; GORRIL et al., 2016). Preclinical studies in rats showed significant anatomical changes and blastocysts, as well as abortive activity, when extracts of $P$. boldus were administered during the gestational period. The possible mechanism to elucidate the increase in embryo loss would be a relaxing effect on tubal mobility, thus influencing the transport of the embryo to the uterus and its subsequent implantation (VASCONCELOS, VIEIRA and VIEIRA, 2009; RODRIGUES et al., 2011).

\section{Lemongrass}

Lemongrass (Cymbopogon citratus), is considered a herbaceous species belonging to the family Poaceae, with long aromatic leaves, originating in India and found diffused in several countries, and acclimatised in the tropical regions of Brazil (SANTOS et al., 2009). It contains phytochemicals in its composition such as combopogonol, citral and myrcene, which may cause risks during pregnancy because they are associated with the stimulus of relaxation of the uterus (FERRO, 2008; GORRIL et al., 2016).

\section{Ginger}

Ginger (Zingiber officinale roscoe) has effective pharmacological action in the treatment of nausea and vomiting during pregnancy. With regard to toxicity, Heitmann, Nordeng and Holst (2013) demonstrated through a cut-off study of 68,522 women that the use of ginger during pregnancy was not associated with an increased risk of congenital malformation, low birth weight, preterm delivery, and stillbirths. According to Lete and Allué (2016) for the treatment of nausea and emesis occasioned by pregnancy, ginger has been shown to be a low-cost and efficient alternative, however, the need for additional clinical studies can not be excluded in order to guarantee the use of this plant.

\section{Rosemary}

Rosemary (Rosmarinus officinalis) also popularly known as rosemary, garden rosemary, house rosemary, common rosemary, true rosemary and rosemary is considered one of the most popular plants in the world due to its healing properties , antimicrobial and digestive (SILVA et al., 2009; HUSSAIN et al., 2010). In relation to its use during gestation, the plant promotes pre-implantation abortion, without causing teratogenesis or fetotoxicity (MEDVED, 2015).

\section{Rue}

The rue (Ruta graveolens) is a plant commonly used as an analgesic in the form of tea by the infusion of its leaves (OLIVEIRA et al., 2015). It has been found that its use can cause reduction of female fertility (NASIRINEZHAD et al., 2009). In addition, aqueous extracts of the rue may be harmful early in gestation as they may interfere with the pre-implantation stages and the transport of the embryo to the uterus. In addition, they cause abnormal embryo growth in the morula and blastocyst stages (SILVA et al., 2012).

\section{Fennel}

Fennel (Foeniculum vulgare) in the gestational period has an estrogenic effect with risk of miscarriage (RAHIMI, ARDEKANI, 2013; SADEGHPOUR et al., 2015), without evidence of teratogenicity or mutagenicity (EBEED et al., 2010), the plant can also generate a decrease in gestational time (TRABACE et al, 2015). 


\section{Copaiba oil}

In a study carried out with Wistar rats, the effects of copaiba oil (Copaifera duckei dwyer), added in vaginal cream on the reproductive performance of pregnant female rats (Rattus norvegicus) were evaluated. These rodents were submitted to the use of vaginal cream containing $2.5 \%$ copaiba oil for 30 days before pregnancy and from day zero to day 20 during pregnancy, and it was verified that there were no problems with: weight of the baby (skeletal and visceral malformations), evidencing that vaginal cream containing oleoresin at $2.5 \%$ copaiba is safe during pregnancy of female rats of the Wistar lineage (LIMA, et al., 2011).

\section{Giant Fedegoso}

The aqueous extract of giant fedegoso (Senna alata) demonstrated abortive effect in study with female Wistar rats. Abortive properties were more pronounced at 500 and $1000 \mathrm{mg} / \mathrm{kg}$ body weight of extract and were similar to animals treated with $2.85 \mathrm{mg} / \mathrm{kg}$ body weight of mifepristone (synthetic steroidal antiprogesterone). The presence of alkaloids, saponins and components of flavonoids isolated or in combination in the constitution of $\mathrm{S}$. alata are the possible responsible for this effect, affecting hormonal and endometrial alterations (YAKUBU et al., 2010).

\section{Basil}

Basil is a medicinal and aromatic plant, also known as alfavaca, alfavaca-cheirosa, basílica or common basil, is the species of the Lamiaceae family most intensely cultivated in Brazil. The basal hydroalcoholic extract (Ocimum basilicum) has a harmful effect on fertility, triggered by its anti-ovulatory action, which may be linked to an increase in progesterone level (FAVORITO et al., 2011).

\section{Saint John's herb}

Saint John's herb (Hypericum perforatum) is a medicinal plant that is known to have considerable psychotropic action without reports of side effects and acts on the inhibition of serotonin, dopamine and noradrenaline reabsorption. One study verified the effect of $H$. perforatum under the behavior of pregnant Wistar rats at 10 and 60 days post-treatment. Revealing the efficacy of the plant species during gestation, preventing the onset of postpartum anxiety. However, further studies are needed to ensure their effects and clarify the mechanism of action (VIEIRA et al., 2013).

\section{Thyme}

Thyme (Thymus vulgaris) is an aromatic herb that presents divergences as to its abortive property, some researchers describe it as stimulant (NAGLE et al., 2013) and others do not report fetal abortions or abnormalities (ZEYNALI et al., 2009; DOMARACKÝ et al., 2007).

\section{Pomegranate}

The pomegranate is an infructescence of the pomegranate (Punica granatum), this species is capable of promoting post-implantation abortion (PROMPROM, et al., 2010; MEMARZADEH, et al., 2015). However, it does not have mutagenic potential (VALADARES et al., 2010; ÁVILA et al., 2013). It is suggested the prenatal intake of pomegranate juice due to its fetoprotective action (CHEN, et al., 2012; CHEN, LONGTINE and NELSON, 2013).

\section{Melon of São Caetano}

The melon of São Caetano (Momordica charantia) is a fickle plant that does not have genotoxicity (LAGARTO et al., 2014), embryotoxicity or abortive effect, however, causes maternal toxicity (TRAUTENMULLER et al., 2016). This species promotes pre-implantation abortion, female infertility (AMAH, YAMA and NORONHA, 2012; TUMKIRATIWONG et al., 2014) and teratrogenicity (UCHE-NWACHI, MCEWEN, 2010; TAIWO et al., 2015).

\section{Conclusion:-}

The use of herbal products as a way of controlling fertility is traditional due to its phytochemical composition. However, women are reducing their consumption during pregnancy, worried about their teratogenic potential. The results obtained demonstrate that the use of teas during pregnancy has its restrictions, since they can increase uterine contractions, generating the risk of abortion or premature birth, making it necessary to carry out new studies to better elucidate and guarantee the safe use of medicinal plants during pregnancy. 


\section{References:-}

1. ALEMDAROGLU, N.C. et al. Influência do chá verde e preto sobre a farmacocinética do ácido fólico em voluntários saudáveis: risco potencial de diminuição da biodisponibilidade do ácido fólico. Biopharm Drug Dispos, v. 29, p. 335348, 2008.

2. AMAH, C.I.; YAMA, O. E.; NORONHA, C.C. Infecund evaluation of cycling female Sprague- Dawley rats: An aftermath treatment with Momordica charantia seed extract. Middle East Fertility Society Journal, v. 17, p. 37-41, 2012.

3. ANHESI, N. Et al. Uso de plantas medicinais na gestação. Retec, v. 9, n. 2, p. 101-109, 2016.

4. ARRUDA, J. T. Et al. Efeito do extrato aquoso de camomila (Chamomilla recutita L.) Na prenhez de ratas e no desenvolvimento dos filhotes. Rev. Bras. Plantas med., Botucatu, v. 15, n. 1, p. 66-71, 2013.

5. ÁVILA, R.I. et al. Punica granatum L. Protects mice against hexavalent chromium induced genotoxicity. Brazilian Journal of Pharmaceutical Sciences, v. 49, n. 4, 2013.

6. BADKE, M. R.; et al. Saberes e práticas populares de cuidado em saúde com o uso de plantas medicinais. Texto contexto - enferm. [online], [S.L.], v. 21, n. 2, p. 363-370, 2012.

7. BRASIL. Ministério da Saúde (MS). Caderneta da Gestante. 2014.

8. BRASILEIRO, B.G; PIZZIOLO, V.R; MATOS, D.S; GERMANO, A.M; JAMAL, C.M. Plantas medicinais utilizadas pela população atendida no Programa de Saúde da Família, Governador Valadares, MG, Brasil. Revista Brasileira de Ciências Farmacêuticas, v. 44, n. 4, p. 629-636, 2008.

9. CAMARGO, Francisco Ribeiro. Promoção da saúde Materno-Infantil: grupo reflexivo sobre o uso de plantas medicinais e medicamentos fitoterápicos na gravidez e lactação. 38 f. 2015. Trabalho de Conclusão de Curso (Curso e Graduação em Farmácia- Bioquímica), Bioquímica, Universidade Estadual Paulista, 2015.

10. CAMPOS, S.C.; SILVA, C.G.; CAMPANA, P.R.V.; ALMEIDA, V.L. Toxicidade de espécies vegetais. Rev. Bras. Pl. Med., Campinas, v.18, n.1, supl. I, p.373-382, 2016.

11. CHEN, B.; LONGTINE, M.S.; NELSON, D.M. Punicalagin, a polyphenol in pomegranate juice, downregulates p53 and attenuates hypoxia-induced apoptosis in cultured human placental syncytiotrophoblasts. Am J Physiol Endocrinol Metab, v. 305, 1274-1280, 2013.

12. CHEN et al. Pomegranate juice and punicalagin attenuate oxidative stress and apoptosis in human placenta and in human placental trophoblasts. Am J Physiol Endocrinol Metab, v. 302, 1142-1152, 2012.

13. DOMARACKÝ et al. J. Effects of selected plant essential oils on the growth and development of mouse preimplantation embryos in vivo. Physiol. Res., v. 56, p. 97-104, 2007.

14. EBEED et al. Antimutagenic and chemoprevention potentialities of sweet fennel (Foeniculum vulgare Mill.) Hot water crude extract. J Am Sci, v. 6, n. 9, p. 831-842, 2010.

15. FAVORITO, P. A. Et al. Características produtivas do manjericão (Ocimum basilicum L.) Em função do espaçamento entre plantas e entre linhas. Revista Brasileira de Plantas Medicinais, v. 13, p. 582-586, 2011.

16. FERRO, D. Fitoterapia: conceitos clínicos. São Paulo: Atheneu. Cap. XV, p. 211-214, 2008.

17. GABBE, S.; NIEBYL, J. R.; SIMPSON, J. L.; LANDON, M. B.; GALAN, H. L.; JAUNIAUX, E. R. M.; DRISCOLL, D. A. Obstetrícia: Gravidez Normal e Patológica. Elsevier. 6 ed. São Paulo, 2015.

18. GORRIL, L. E. Et al. Risco das plantas medicinais na gestação: uma revisão dos dados de acesso livre em língua portuguesa. Arquivos de Ciência da Saúde UNIPAR, Umuarama, v. 20, n. 1, 2016.

19. HEITMANN K., NORDENG H., HOLST L. Safety of ginger use in pregnancy: results from a large populationbased cohort study. Eur J Clin Pharmacol., v.69, n.2, p.269-77, 2013.

20. HUSSAIN, A.I. et al. Rosmarinus officinalis essential oil: antiproliferative, antioxidant and antibacterial activities. Braz J Microbiol, v.41, n.4, p.1070-1078, 2010.

21. LETE I, ALLUÉ J. The effectiveness of ginger in the prevention of nausea and vomiting during pregnancy and chemotherapy. Integr Med Insights, v.11, p.11-17, 2016.

22. LIMA, C.S.; DE MEDEIROS, B.J.L.; FAVACHO, H.A.S.; DOS SANTOS, K.C.; DE OLIVEIRA, B.R.; TAGLIALEGNA, J.C.; DA COSTA, E.V.M.; DE CAMPOS, K.J.; CARVALHO, J.C.T. Pre-clinical validation of a vaginal cream containing copaiba oil (reproductive toxicology study). Phytomedicine, v.18, p. 1013-1023, 2011.

23. LAGARTO et al. Evaluación preclínica y estudio de estabilidad de extractos a partir del follaje de Momordica charantia Lin. Rev. Bras. Pl. Med., v. 16, n. 4, p. 782-788, 2014.

24. KAYIRAN, S. M.; INCE, D. A.; ALDEMIR, D.; GURAKAN, B. Investigating the Effect of Black Tea Consumption During Pregnancy on the Oxidant/Antioxidant Status of Breastmilk. Breastfeeding Medicine, v. 8, n. 2, p. 187-190, 2013.

25. MEDVED, V. Safety of Canephron ${ }^{\circledR} \mathrm{N}$ for the treatment of urinary tract infections in the first trimester of pregnancy. Clinical Phytoscience, v. 1, n. 1, 1-6, 2015.

26. MEMARZADEH et al. Evaluation of efficacy of Punica granatum L. (Persian gulnar) on uterine leiomyoma related menorrhagia: a pilot study. International Journal of Biosciences, v. 6, n. 9, p. 18- 25, 2015.

27. NASIRINEZHAD et al. Antifertility effect of aqueous extract of airal part of Ruta graveolens on immature female Balb/C mice. Physiology and Pharmacology, v. 13, n. 3, p. 279-287, 2009. 
28. NORDENG, H.; HAVNEN, G.C. Use of herbal drugs in pregnancy: a survey among 400 Norwegian women. Pharmacoepidemiol Drug Saf, v. 13, p. 371-380. 2004.

29. NUNES, J. D.; MACIEL, M. V. A. Importância da informação do profissional de enfermagem sobre o cuidado no uso das plantas medicinais: uma revisão de literatura. Revista Fitos, Rio de Janeiro, v. 10, 375-547. 2016.

30. OLIVEIRA, F. A.; CONDE, B. E.; GOMES, F. T; FONSECA, A. S.; CAMPOS, B. C. Potencial de cura e segurança do uso de plantas medicinais na utilização do método da biodigital como tratamento alternativo no grupo de medicina alternativa em Juiz de Fora, MG. Persp. Online: Biológicas e da Saúde, v. 5, n 17, p. 47-63, 2015.

31. PIRES, A. M.; ARAÚJO, P. S. Percepção de risco e conceitos sobre plantas medicinais, fitoterápicos e medicamentos alopáticos entre gestantes. Revista Baiana de Saúde Pública, v. 35, n.2, p.320-333, 2011.

32. PROMPROM et al. The effects of pomegranate seed extract and $\beta$-sitosterol on rat uterine contractions. Reproductive Sciences, v. 17, n. 3, p. 288-296, 2010.

33. RAHIMI, R.; ARDEKANI, M.R.S. Medicinal properties of Foeniculum vulgare Mill. In traditional Iranian medicine and modern phytotherapy. Chinese journal of integrative medicine, v. 19, n. 1, p. 73-79, 2013.

34. RODRIGUES, H. G. Et al. Efeito embriotóxico, teratogênico e abortivo de plantas medicinais. Revista Brasileira de Plantas Medicinais, v.13, n.3, p. 359-366, 2011.

35. RUIZ, A. L. T. G. Et al. Pharmacology and toxicology of Peumus boldus and Baccharis genistelloides. Revista Brasileira de Farmacognosia, v. 18, n. 2, p. 295-300, 2008.

36. SADEGHPOUR et al. Study of Foeniculum vulgare (Fennel) Seed Extract Effects on Serum Level of Estrogen, Progesterone and Prolactin in Mouse. A. General Policy, v. 2, p. 23-27, 2015.

37. SANFEliCE, C.; SANTOS, C. C.; WILHELM, L. A.; AlVES, C. N.; BARRETO, C. N.; RESSEL, L. B. Saberes e práticas de cuidado de gestantes de uma unidade básica de saúde. Rev. Enferm UFPE on line, v. 7, n. 12, p. 67906799, 2013.

38. SANTOS, A. Et al. Determinação do rendimento e atividade antimicrobiana do óleo essencial de Cymbopogon citrarus (DC.) Stapf em função de sazonalidade e consorciamento. Revista Brasileira de Farmacognosia, v. 19, n. 2, p. 436-441, 2009.

39. SILVA, M.T.N. et al. Atividade antibacteriana de óleos essenciais de plantas frente a linhagens de Staphylococcus aureus e Escherichia coli isoladas de casos clínicos humanos. Rev Bras Plantas Med, v.11, n.3, p.257-263, 2009.

40. SILVA, R. C. Et al. Plantas medicinais utilizadas na saúde da mulher: riscos na gravidez. Diálogos \& Ciência, v. 1, n.32, p. 20-28, 2012.

41. SRIDHARAN, S.; ARCHER, N.; MANNING, N. Premature constriction of the fetal ductus arteriosus following the maternal consumption of camomile herbal tea. Ultrasound Obstet Gynecol. ISUOG, Department of Fetal and Paediatric Cardiology, John Radcliffe Hospital, Oxford, UK. 2009.

42. TAIWO, I. Et al. Teratogenic and Anti-mutagenic Potentials of Aqueous Leaf Extract of Momordica charantia Linn. International Journal of Sciences: Basic and Applied Research, v. 22, n. 1, p. 384-392, 2015.

43. TRABACE, L. Et al. "Natural" relief of pregnancy-related symptoms and neonatal outcomes: above all do no harm. Journal of Ethnopharmacology, v. 174, p. 396-402, 2015.

44. TRAUTENMÜLLER, J. Et al. Variação longitudinal da massa específica básica da madeira de Cordia americana e Alchornea triplinervia. Ciência Rural, Santa Maria, v. 44, n. 5, p. 817- 821, 2014.

45. TUMKIRATIWONG et al. Reproductive toxicity of Momordica charantia ethanol seed extracts in male rats. Iran J Reprod Med, v. 12, n. 10, p. 695-704, 2014.

46. UCHE-NWACHI, E.O.; MCEWEN, C. Teratogenic effect of the water extract of bitter gourd (Momordica charantia) on the sprague dawley rats. Afr. J. Trad., v. 7, n. 1, p. 24-33, 2010.

47. VALADARES et al. Assessment of mutagenic and antimutagenic effects of Punica granatum in mice. Brazilian Journal of Pharmaceutical Sciences, v. 46, n. 1, 2010.

48. VASCONCELOS, J.; VIEIRA, J. G. P.; VIEIRA, E. P. P. Plantas tóxicas: conhecer para prevenir. Revista Científica da UFPA, Belém, v. 7, n. 01, p. 1-6, 2009.

49. VIEIRA, V. A. Et al. Evaluation of postpartum behaviour in rats treated with Hypericum perforatum during gestation. Revista Brasileira de Farmacognosia, v. 23, n. 5, p. 796-801, 2013.

50. YAKUBU, M. T. Et al. Abortifacient potential of aqueous extract of Senna alata leaves in rats. Journal of reproduction and contraception, v. 21, n. 3, p. 163-177, 2010.

51. ZEYNALI et al. The effect of thyme decoction on pregnancy in rats. International Journal of Reproductive Biomedicine, v. 7, n. 2, 2009. 